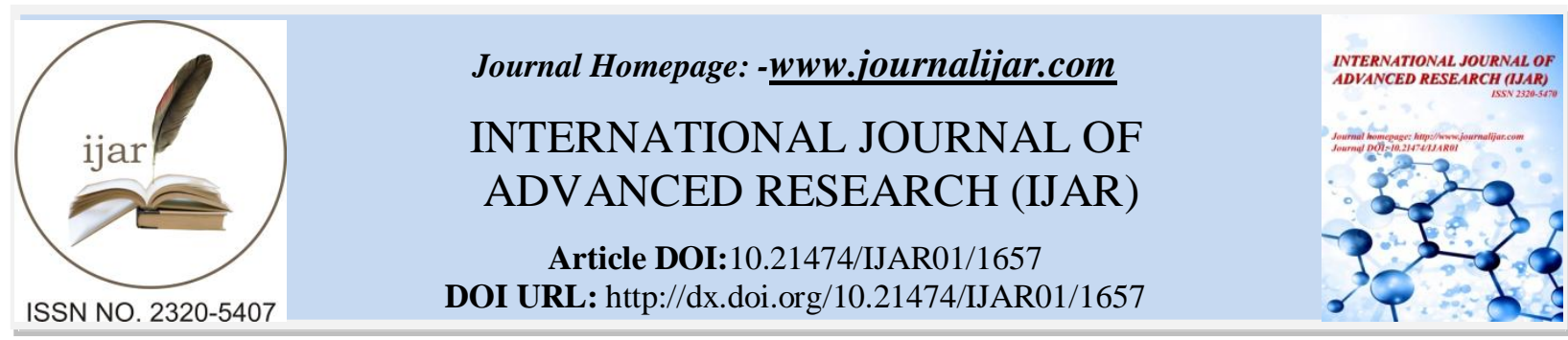

RESEARCH ARTICLE

\title{
CLINICAL AND MORPHOLOGICAL CHARACTERISTICS OF NSCLC AND VEGF GENE POLYMORPHISM.
}

\author{
Mikhail N. Shapetska ${ }^{1}$, Anna N. Shchayuk ${ }^{2}$, Elena P. Mikhalenko ${ }^{2}$, Natalia V. Chebotareva ${ }^{2}$, Svetlana N. \\ Pisarchik ${ }^{3}$ and Evelina V. Krupnova ${ }^{2}$. \\ 1. Belarusian State Medical University, Minsk, Republic of Belarus. \\ 2. Institute of Genetics and Cytology NAS of Belarus, Minsk, Republic of Belarus, \\ 3. City Clinical Pathologoanatomic Bureau, Minsk, Republic of Belarus.
}

\section{Manuscript Info}

(.........................

Manuscript History

Received: 12 July 2016

Final Accepted: 19 August 2016

Published: September 2016

Key words:-

NSCLC, VEGF gene, polymorphisms,

histological type, survival

\section{Abstract}

Our study shown prognostic effect of $V E G F$ gene polymorphisms on clinical features of NSCLC. As vascular endothelial growth factor (VEGF) is a major driver of angiogenesis and cancer cells proliferation, we evaluated survival the group of patients with NSCLC from the position of $V E G F$ gene polymorphisms, TNM and histological types of tumor. Analysis revealed that polymorphisms $V E G F$ gene influence the outcome of treatment, histological type, size, metastasis as aggressiveness of the NSCLC.

Copy Right, IJAR, 2016,. All rights reserved.

\section{Introduction:-}

Lung cancer is a leading cause of cancer-related death worldwide. Annually, over 1.2 million people are diagnosed as having lung cancer, and 1.1 million die from the disease (Parkin et al, 2001). Despite an intensive research over the past decades, the five-year survival of patients with lung cancer remains poor (Jemal A, et al, 2004).

In lung cancer, the prognosis mainly depends on the disease stage, histological characteristics and metastatic potential of the primary tumor. Following the combined/complex treatment of non-small cell lung cancer (NSCLC), the survival at stage 1 of the disease makes 40-50\%, at stage $2-15-30 \%$ [http://bioinfo.iconcologia.net/snpstats/start.htm]. In advanced cases or unrespectable tumors, the radiotherapy results in a 5-year survival in 4-8\% of patients only. Up to $90 \%$ of patients die within the first two years after the diagnosis if a special treatment is not given. The mediastinal lymph nodes involvement dramatically reduces the life expectancy for NSCLC patients in particular. Even a single mediastinal lymph node invasion is considered to be an unfavorable prognostic factor in NSCLC (Peng Lv., 2014)

The aggressive clinical course is typical for the squamous cell cancer as well as for adenocarcinoma due to their histological structure. However, the difference in the life expectancy can vary depending on the degree of the neoplasm differentiation. Well differentiated adenocarcinoma and squamous cell cancer are less aggressive as compared to poorly differentiated carcinomas, which early spread to mediastinal lymph nodes (Furrukh, et al. 2013).

Individual genetic features of patients may affect the prognosis for NSCLC clinical course. Taking into account multiple aspects when assessing the prognosis and choosing an adequate treatment strategy for malignancies, one of the main oncological issues nowadays is to study the role of growth factors in neoangiogenesis. 
Vascular endothelial growth factor (VEGF) is a major driver of angiogenesis, which stimulates endothelial cell growth and cancer cells proliferation. Functional polymorphic sites determining the level of VEGF production have been detected in the promoter, the 5-untranslated and the 3'-untranslated gene regions (Watson C., et al. 2000; Lambrechts D., et al. 2003; Schneider B., et al. 2008). Molecular markers can be beneficial for individual prognosis of clinical outcomes in NSCLC.

In this article, the results of our study aimed at investigating the prognostic effect of rs699947, rs2010963 and rs3025039 VEGF gene polymorphisms on clinical features of NSCLC are presented.

\section{Materials and methods:- \\ Subjects:-}

276 patients diagnosed as having NSCLC and treated at the Minsk City Oncology Dispensary during the period from 2003 to 2015 were included in the study. The study group consisted of patients with NSCLC stage $1-4$ according to the TNM Classification of Malignant Tumours (http://www.uicc.org/sites/main/files/private/) who underwent surgery. The diagnosis of lung cancer has been based on clinical picture of the disease, history data, bronchoscopy, X-ray examination and computed tomography, cytomorphology of sputum and tumor tissue biopsies.

The histological type of lung carcinoma was determined according to the WHO histological criteria. The group of NSCLC included the most common neoplasms - squamous cell carcinoma and adenocarcinoma.

The study was performed in compliance with the principles of voluntary participation and confidentiality, in accordance with in accordance of informed consent for patients. The study protocol was approved by the local Ethics Committee.

\section{Methods:-}

DNA was extracted from peripheral blood with the phenol-chloroform method. Rs2010963, rs699947, rs3025039 $V E G F$ gene polymorphisms were genotyped by the polymerase chain reaction and the restriction fragment length polymorphism (PCR-RFLP) analysis using specific primers ("Primetech", Minsk, Republic of Belarus) and restriction endonucleases. The reagents for PCR and PCR-RFLP used from "Thermo Fisher Scientific" (Vilnius, Lithuania). After the PCR-RFLP, the samples were visualized under UV light.

\section{Statistical analysis:-}

Statistical analyses were performed using Statistica 7.0, GraphPadInStat Version 3.05 and SPSS Statistics 17.0. When comparing genotype frequencies, Pearson's chi-squared test $(\chi 2)$ was used. The association between the genotypes, haplotypes and the disease course was assessed by odds ratio (OR (95\% CI)) using the co-dominant model SNPStats (http://bioinfo.iconcologia.net/snpstats/start.htm?). Overall survival was calculated as the time from the date of operation to the date of last contact with patient or the date of death. Survival was estimated using Kaplan-Meier method and compared using log-rank test. Prognostic factors were first determined using univariate Cox proportional hazard model. Variables with a p-value less than 0.10 after univariate analysis entered into multivariate analysis using the Cox proportional hazards model. $\mathrm{P}<0.05$ testified to a statistical significance.

\section{Results:-}

Clinical characteristics of NSCLC patients are shown in Table 1.The median age was 61,4 years (age range 36 to 92 years), male-female ratio was 1:3 (22,8\% females : $77,2 \%$ males). $56,8 \%$ of patients were cigarette smokers at the time of the surgery, 33, 3\% never smoked, and the smoking status is not known in 9,9\%. The patients have been surgical treated according to the degree of tumor spreading and their functional condition. Lobectomy/bilobectomy or atypical resection was performed in $68,5 \%$ of patients. $27 \%$ of subjects underwent pneumonectomy. In $4 \%$ of cases, only the pulmonary biopsy was carried out, with the surgery not done because of poor lung capacity. 
Table 1:- Characteristics of study population.

\begin{tabular}{|c|c|c|}
\hline Characteristics & Patients with NSCLC, $\mathrm{n}=276$ & $\%$ \\
\hline Average age & 61,4 & \\
\hline \multicolumn{3}{|l|}{ Gender: } \\
\hline female & 63 & 22,8 \\
\hline male & 213 & 77,2 \\
\hline \multicolumn{3}{|l|}{ Stage: } \\
\hline I & 111 & 40,2 \\
\hline II & 50 & 18,2 \\
\hline III (III a) & $84(49)$ & $30,4(17,8)$ \\
\hline IV & 17 & 6,2 \\
\hline \multicolumn{3}{|l|}{ Histology: } \\
\hline Squamous-cell carcinoma & 144 & 52,2 \\
\hline Adenocarcinoma & 132 & 47,8 \\
\hline \multicolumn{3}{|l|}{ Surgery: } \\
\hline lobectomy/bilobectomy & 175 & 63,4 \\
\hline pneumonectomy & 76 & 27,5 \\
\hline lung resection & 14 & 5,1 \\
\hline biopsy & 9 & 3,3 \\
\hline surgical treatment is not carried out & 2 & 0,7 \\
\hline \multicolumn{3}{|l|}{ Smoking status: } \\
\hline does not smoke & 92 & 33,3 \\
\hline smokes & 157 & 56,8 \\
\hline no information & 27 & 9,9 \\
\hline \multicolumn{3}{|l|}{ SNPs $V E G F$} \\
\hline \multicolumn{3}{|l|}{ rs2010963 } \\
\hline $\mathrm{AA}$ & 58 & 21 \\
\hline $\mathrm{AC}$ & 138 & 50 \\
\hline $\mathrm{CC}$ & 80 & 30 \\
\hline \multicolumn{3}{|l|}{ rs699947 } \\
\hline $\mathrm{AA}$ & 58 & 21 \\
\hline $\mathrm{AC}$ & 137 & 49 \\
\hline $\mathrm{CC}$ & 77 & 29 \\
\hline \multicolumn{3}{|l|}{ rs3025039 } \\
\hline $\mathrm{CC}$ & 196 & 71 \\
\hline $\mathrm{CT}$ & 69 & 25 \\
\hline $\mathrm{TT}$ & 11 & 4 \\
\hline
\end{tabular}

Most patients had the disease stage $1-2$ with the tumor subject to resection. According to TNM/pTNM classification, $23,5 \%$ had pT1N0 tumor, $22,8 \%$ of patients presented with pT2N0 that in total makes $46,3 \%$. The tumor did not invade the mediastinal lymph nodes in 51, $8 \%$ of cases. In $48,2 \%$, the tumor spread, and mediastinal lymph nodes N1, N2 and N3were involved in 21,7\%, 25,4\% and 1,1\%, respectively. In our study, the overall 3-year survival made $64 \%$, 5-year survival - 49\%, 10-year survival - 23\%. The median survival during 10 years accounted to 46,8 (Figure 1). 


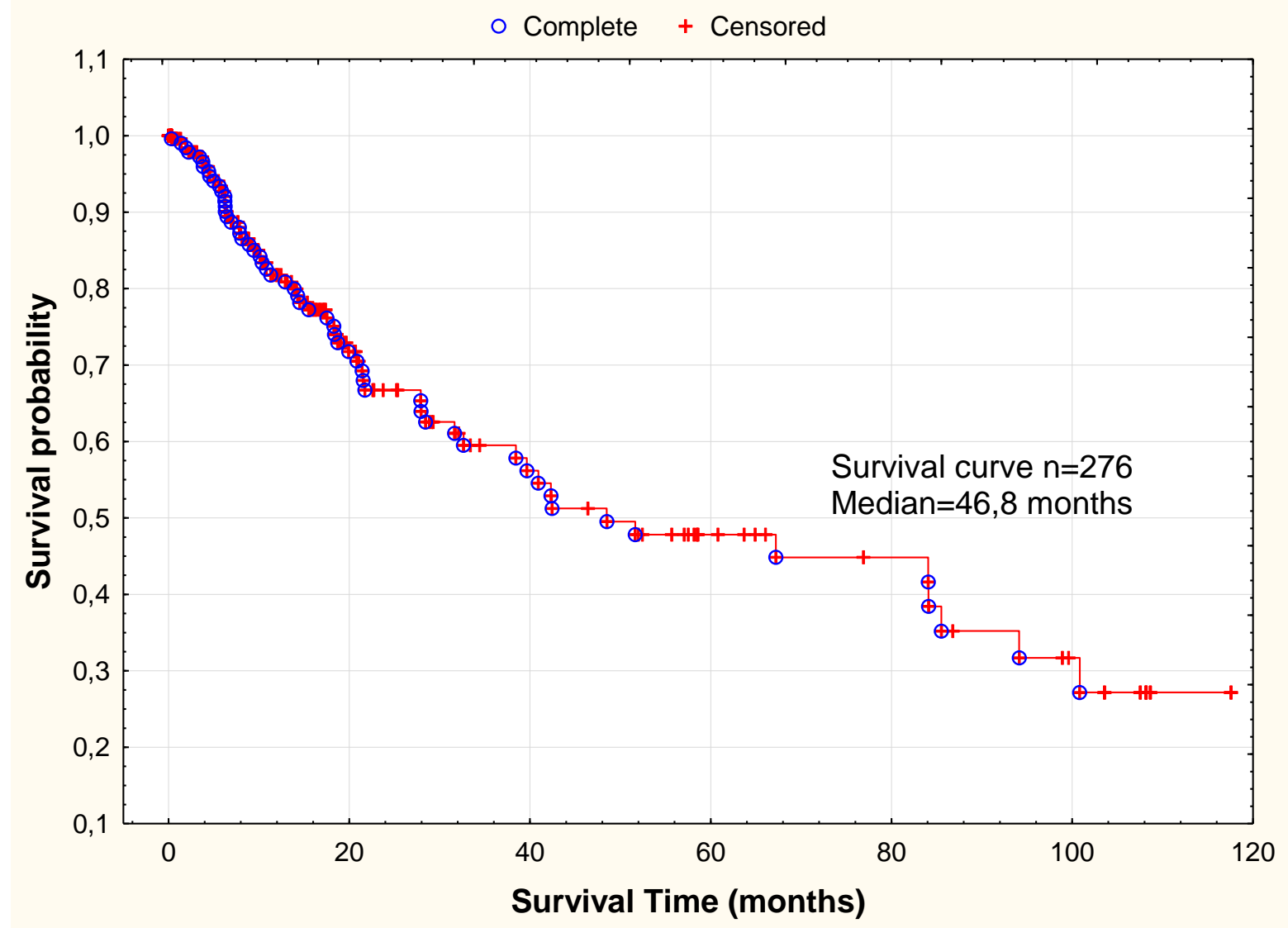

Fig. 1:- Overall survival of patients with NSCLC (general group)

When considering the clinical features such as disease stage, tumor size, regional metastases, histological tumor type and their effect on the overall survival, it has been shown that the stage of the disease was a significant factor in the survival prognosis $(\chi 2=23,27698 ; p=0,00004)$. A 3 -year survival of patients with NSCLC stage 1 made $84,9 \%, 5$ year survival $-62,1 \%$. In patients at stage 2 , a 3 -year survival made $73,2 \%$, and a 5 -year survival $-34,4 \%$. At stages 3-4, 3-year and 5-year survival rates were less than $10 \%$ (Figure 2). Nevertheless, some patients with the stage 3-4 survived the disease for more than 5 years, which corresponds to the data of the National Cancer Institute (USA) (http://seer.cancer.gov/csr 1975_2013). 


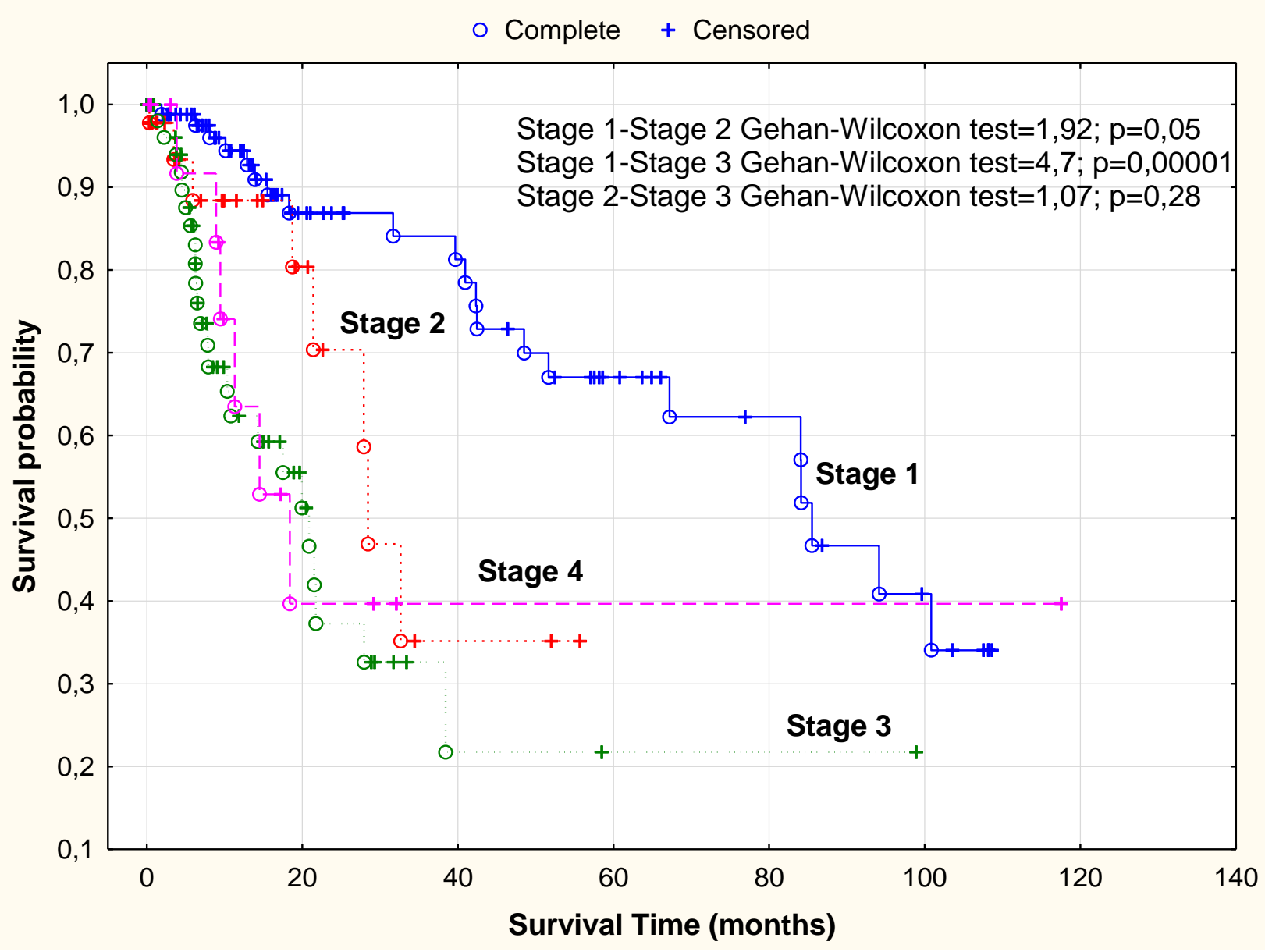

Fig. 2:- Overall survival of patients with NSCLC according to the stage of disease

When the tumor spreads to the mediastinal lymph nodes, the criterion $\mathrm{N}$ was the most significant for predicting the survival in NSCLC in the study group. Patients with not involved mediastinal lymph nodes have the best survival prognosis. A 3-year survival for N0 made 73,5\%, a 5-year survival - 59,0\%. With a single lymph node being involved, the prognosis dramatically worsened. 3-year survival for patients with $\mathrm{N} 1$, depending on the tumor spread to the regional lymph nodes of the mediastinum was $46,0 \%$ (Gehan test $=2,75 ; \mathrm{p}=0,006$ ). Only 1 patient survived the disease for more than 5 years.

The more lymph nodes were involved, the worse prognosis was observed. According to our data, a 3-year survival for patients with N2 made 33\%. Only 1 patient at N1 approached a 5-year survival. No one patient at N3 survived the disease for more than 3 or 5 years. The median life expectancy for patients with N0 accounted to 22,6 months, $\mathrm{N} 1-10,7$ months, $\mathrm{N} 2-9,3$ months, and N3 - 2,4 months. The data were statistically significant for the group in general, $(\mathrm{p}=0,005)$, but the results of Gehan-Wilcoxon test sand $\mathrm{p}$-values for each $\mathrm{N}$ group were different. The involvement of more than one lymph node has been to reduce the overall survival in lung cancer significantly (Figure 3). 


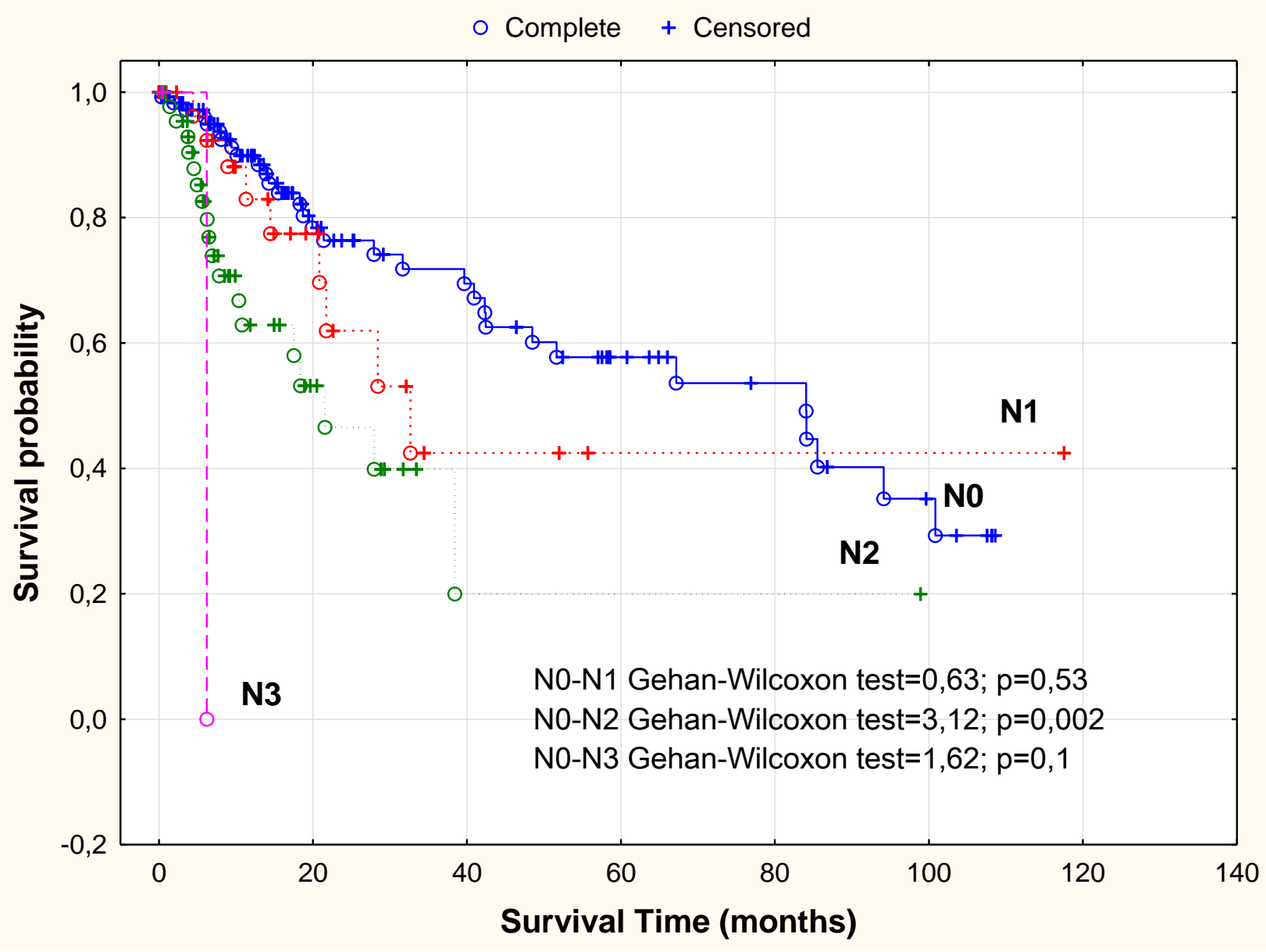

Fig. 3:- Overall survival of patients with NSCLC according to N0, N1, N2, N3

Morphological characteristics of the tumor are also a very informative factor affecting the survival rate of patients with NSCLC. In squamous cell cancer due to early metastases spread, the outcomes of treatment could be worse as compared to those in carcinomas (Figure 4). In our study, a 3-year survival of patients with squamous cell cancer was $51,3 \%$, a 5-year survival -43,0\%. A 3-year survival of patients with adenocarcinoma was 78,7\%, a 5-year survival $-63,5 \%$. Thus, the patients with adenocarcinoma have more chances to survive the disease for more than 5 years as compared to those with squamous cell cancer $(\mathrm{p}=0,08)$. 


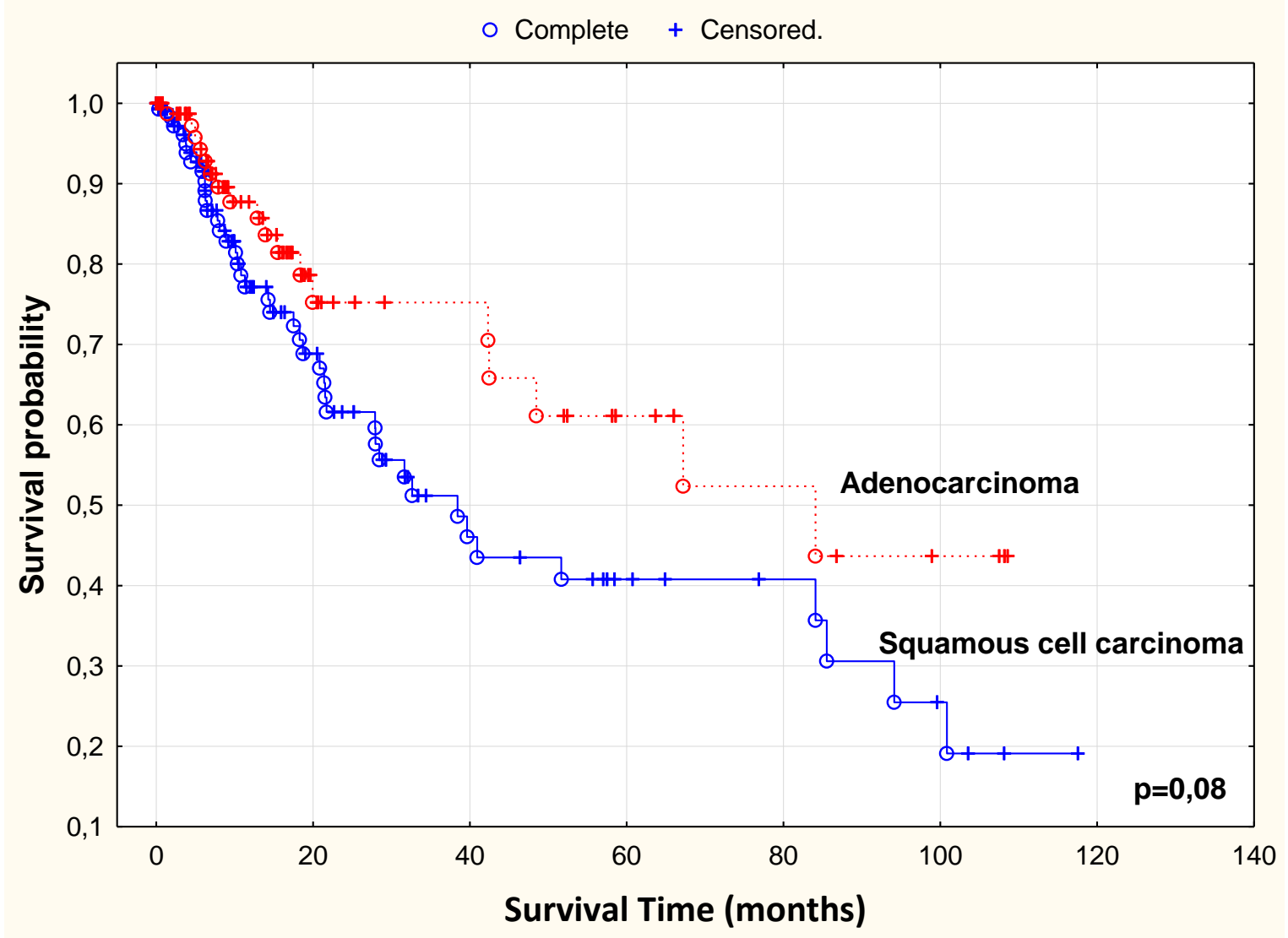

Fig. 4:- Overall survival of patients with NSCLC according to the tumor histological type

These results are significant in the univariate analysis model. We decided to check the adequacy of the prognostic assessment of clinical and morphological characteristics with survival of patients. For that we used multivariate analysis of the Cox proportional hazards model. In multivariate analysis were strongly associated poor prognosis for the patients with stage $2-(\mathrm{HR}=3,351,19-10,55, \mathrm{p}<0,023), 3-(\mathrm{HR}=4,441,21-16,24, \mathrm{p}<0,024)$ и $4-(\mathrm{HR}=$ $4,721,09-20,48, \mathrm{p}<0,038)$ compared with stage 1 of disease. The size of the tumor, regional metastasis, morphological type and polymorphic variants of the gene $V E G F$ are likely to affect the survival of patients (Table 2). Table 3 shows the results of association of polymorphisms rs2010963, rs699947, rs3025039 of gene VEGF with morphological tumor type and development of NSCLC (tumor size, disease stage and metastasis). It is shown that polymorphic variant $+936 \mathrm{TT} V E G F$ gene is significantly more frequent in patients with squamous cell lung cancer $(\mathrm{OR}=4,37 \mathrm{CI}: 1,09-24,63 ; \mathrm{p}=0.049)$. The influence of polymorphism rs699947 VEGF gene on the clinical characteristics of the tumor has been revealed. A greater degree of spread of the tumor (T2 - T4) was observed in patients with genotype $-2578 \mathrm{CC}$ more frequently $(\mathrm{p}=0.005)$. Patients with genotype $-2578 \mathrm{AA}$ are significantly less likely to have the 3rd stage of the disease $(\mathrm{p}=0.012)$, develop less metastasis of the primary tumor in the regional lymph nodes $(p=0.0098)$ and do not develop multiple lesions of lymph nodes, compared to patients with genotype $-2578 \mathrm{CC}$. Haplotype analysis (Table 4) of the three studied polymorphisms of the VEGF gene showed significant association of haplotype $-634 \mathrm{C} /-2578 \mathrm{C} /+936 \mathrm{C}$ with a small non-invasive cancer $(\mathrm{p}=0.0068)$. Haplotype carriers $-634 \mathrm{G} /-2578 \mathrm{C} /+936 \mathrm{C}$ revealed high aggressiveness of the disease (stage $-\mathrm{p}=0.0061$; regional metastasis $-\mathrm{p}=$ $0.0014)$.

\section{Discussion:-}

Angiogenesis is an important factor for the primary tumor growth, invasion and metastasis. Vascular endothelial growth factor (VEGF) is the main cytokine mediator of angiogenesis and is considered as the base process in the initiation of angiogenesis. It was revealed that some polymorphisms in the VEGF gene increase the expression of the gene in different oncological processes (Nakamura M, 2002; Nasr HB., 2008). Polymorphic variants of genes 634CC and -2578CC are associated with high levels of VEGF protein product in the blood plasma (Shahbazi M, et al. 2002; Awata, T., 2002), whereas +936TT genotype relates to low levels of protein plasma (Krippl P, et al. 2003). 
The expression level of VEGF in tumor tissue is higher than in non-tumor one, and its over-expression indicates poor prognosis of the disease (L. Jain, et al. 2009; H. Fukuda, et al. 2007). This points to the prognostic importance of the study of polymorphisms of this gene in the development of various cancers (L. Jain, et al. 2009; H.P. Dhakal, et al.,2012; Slattery ML, 2014; Kawakami, M. et al. 2003), in particular lung cancer.

The relationship between the level of angiogenesis in the tumor, its size and metastasis are confirmedby the correlation between disease course and primary tumor microvessel density (Nasr HB. et al., 2008; Perrot-Applanat, M. et al., 2012; Park H., et al., 2015). Various polymorphisms in the VEGF gene are associated with lymphatic and hematogenous metastasis in various malignancies (Kawakami, M. et al., 2003; Nasr HB. et al., 2008)

$V E G F$ gene provides an alternative splicing that forming a family of proteins. $V E G F$ gene provides an alternative splicing, which forms a family of proteins. There is considerable variation between individuals in VEGF expression. Polymorphism $+936 \mathrm{C}>\mathrm{T}$ is localized in the 3 'untranslated region, polymorphism $-634 \mathrm{G}>\mathrm{C}$ VEGF gene located in the 5'-untranslated region and single nucleotide substitution $V E G F$ gene $\mathrm{C}>\mathrm{A}$ is localized in promoter zone of point 2578 of gene $V E G F$ gene. These regions contain key regulatory elements that are sensitive to hypoxia (Nowell, S.A., 2004; Sheng, Z. et al., 2006; Cianfrocca R. et al., 2016) and contribute to high variability of VEGF protein product formation (Sheng, Z. et al., 2006). Moreover, $-634 \mathrm{G}>\mathrm{C}$ polymorphism is located in a potential transcription factor binding site MZF1 (Awata, T., 2002) and polymorphism + 936C> T leads to the loss of the potential binding site of AP-4, (Shahbazi M, et al. 2002; Krippl P, et al., 2003), resulting in non-formation of the protein product. Schneider (Sheng, Z. et al., 2006) point that a single nucleotide polymorphism, localized in the promoter region or the 3 ', 5'-untranslated regions, affects protein expression at the transcriptional level. Initially, hypoxia-induced factor $\left(\mathrm{HIF}^{*} 1\right)$ is attached to the $V E G F$ gene in the promoter region (polymorphism -2578S> A). Gene polymorphism in this region may weaken or strengthen this interaction, therefore alter the expression of VEGF (2578S > A) (Heist R.,et al., 2008), which in turn, affects the formation and microvessel permeability, and as a result, the size of the tumor, metastasis and survival.

The above mentionned fact might explain that there is a greater degree of tumor spread in homozygous carriers in our study (-2578CC). Lower levels of VEGF expression in the presence of -2578A allele apparently provides a protective effect in homozygous genotypes (-2578AA) carriers associated with a lower spreading of tumors (Table $3)$.

High levels of VEGF expression is associated with increased risk of disease recurrence and decreased survival rates of people with a variety of oncological processes (Awata, T., et al., 2002). We can assume it is the contribution of the genotype (-2578CC) $V E G F$, that determines the high level of expression of the corresponding protein product in the progression of NSCLC, which has been confirmed by our research.

We did not find the effect of the VEGF gene polymorphisms on survival in our cohort of patients with advanced NSCLC, although the works of Rebecca Suk Heist et al. demonstrated that patients with higher number of variant alleles of the $-634 \mathrm{G}>\mathrm{C}$ and $+936 \mathrm{C}>\mathrm{T}$ polymorphisms had better survival (Kawakami, M. et al., 2003).

Table 2:- Summary of the patient and tumor characteristics and their prognostic effect

\begin{tabular}{|c|c|c|c|c|c|c|}
\hline & \multicolumn{6}{|c|}{ Overall Survival } \\
\hline \multirow[t]{2}{*}{ Characteristic } & \multicolumn{3}{|c|}{ Univariate Cox model } & \multicolumn{3}{|c|}{ Multivariate Cox model } \\
\hline & $\mathrm{p}$ & HR & $95,0 \% \mathrm{CI}$ & $\mathrm{p}$ & HR & $95,0 \% \mathrm{CI}$ \\
\hline Stage & $<0,001$ & & & 0,071 & & \\
\hline 1 & & 1,00 & - & & 1,00 & - \\
\hline 2 & 0,043 & 2,38 & $1,03-5,50$ & 0,023 & 3,55 & $1,19-10,55$ \\
\hline 3 & $<0,001$ & 4,04 & $2,16-7,54$ & 0,024 & 4,44 & $1,21-16,24$ \\
\hline 4 & 0,024 & 2,88 & $1,15-7,20$ & 0,038 & 4,72 & $1,09-20,48$ \\
\hline Tumor Size & 0,001 & & & 0,800 & & \\
\hline $\mathrm{T} 1$ & & 1,00 & - & & 1,00 & - \\
\hline $\mathrm{T} 2$ & 0,417 & 1,31 & $0,69-2,49$ & 0,541 & 1,23 & $0,63-2,36$ \\
\hline $\mathrm{T} 3$ & 0,001 & 3,97 & $1,75-9,01$ & 0,334 & 1,62 & $0,61-4,31$ \\
\hline $\mathrm{T} 4$ & 0,004 & 3,23 & $1,46-7,14$ & 0,710 & 1,25 & $0,39-3,99$ \\
\hline Lymph Node Metastasis & 0,003 & & & 0,160 & & \\
\hline
\end{tabular}




\begin{tabular}{|l|c|c|c|c|c|c|}
\hline N0 & & 1,00 & - & & 1,00 & - \\
\hline N1 & 0,391 & 1,39 & $0,66-2,94$ & 0,074 & 0,40 & $0,15-1,09$ \\
\hline N2 & 0,002 & 2,65 & $1,43-4,91$ & 0,661 & 0,78 & $0,26-2,38$ \\
\hline N3 & 0,014 & 13,07 & $1,69-101,19$ & 0,272 & 3,48 & $0,38-32,14$ \\
\hline Histological types & & & & & & \\
\hline Squamous cell carcinoma & & 1,00 & - & & 1,00 & - \\
\hline Adenocarcinomas & 0,059 & 0,59 & $0,34-1,02$ & 0,208 & 0,68 & $0,38-1,24$ \\
\hline SNPs VEGF & & & & & & \\
\hline rs2010963 & 0,32 & & & & & \\
\hline CC & & 1,00 & - & & & \\
\hline GC & 0,569 & 1,32 & $0,51-3,40$ & & & \\
\hline GG & 0,775 & 0,87 & $0,33-2,31$ & & & \\
\hline rs699947 & 0,972 & & & & & \\
\hline AA & & 1,00 & - & & & \\
\hline AC & 0,984 & 0,99 & $0,52-1,90$ & & & \\
\hline CC & 0,858 & 1,07 & $0,53-2,17$ & & & \\
\hline rs3025039 & 0,448 & & & & & \\
\hline CC & & 1,00 & - & & & \\
\hline CT & 0,211 & 0,62 & $0,29-1,32$ & & & \\
\hline TT & 0,748 & 0,85 & $0,30-2,36$ & & & \\
\hline
\end{tabular}

Table 3:- Association between VEGF Genotypes and Tumor Characteristics in the Belarusian Population.

\begin{tabular}{|c|c|c|c|c|c|c|c|c|c|}
\hline \multicolumn{10}{|c|}{ Polymorphism/genotype } \\
\hline & \multicolumn{3}{|c|}{ rs2010963, n (\%) } & \multicolumn{3}{|c|}{ rs699947, n (\%) } & \multicolumn{3}{|c|}{ rs $3025039, \mathrm{n}(\%)$} \\
\hline & GG & $\mathrm{GC}$ & $\mathrm{CC}$ & $\mathrm{CC}$ & $\mathrm{CA}$ & AA & $\mathrm{CC}$ & CT & TT \\
\hline \multicolumn{10}{|l|}{ Histology: } \\
\hline $\begin{array}{l}\text { Squamous-cell } \\
\text { carcinoma }\end{array}$ & $\begin{array}{c}61 \\
(45.9)\end{array}$ & $\begin{array}{c}63 \\
(47.4)\end{array}$ & $9(6.8)$ & $\begin{array}{c}35 \\
(26.3)\end{array}$ & $74(55.6)$ & $24(18.1)$ & $\begin{array}{c}101 \\
(75.9)\end{array}$ & $\begin{array}{c}30 \\
(22.6)\end{array}$ & $2(1.5)$ \\
\hline Adenocarcinoma & $\begin{array}{c}75 \\
(52.5)\end{array}$ & $\begin{array}{c}52 \\
(36.4)\end{array}$ & $\begin{array}{c}16 \\
(11.2)\end{array}$ & $\begin{array}{c}45 \\
(31.5)\end{array}$ & $64(44.8)$ & $34(23.8)$ & $\begin{array}{c}95 \\
(66.4)\end{array}$ & $\begin{array}{c}39 \\
(27.3)\end{array}$ & $9(6.3)$ \\
\hline OR $(95 \% \mathrm{CI})$ & 1.00 & $\begin{array}{c}0.67 \\
(0.41- \\
1.11)\end{array}$ & $\begin{array}{l}1.45 \\
(0.60- \\
3.50)\end{array}$ & 1.00 & $\begin{array}{l}0.67 \\
(0.39- \\
1.17)\end{array}$ & $\begin{array}{c}1.10 \\
(0.56- \\
2.18)\end{array}$ & 1.00 & $\begin{array}{c}1.38 \\
(0.80- \\
2.40)\end{array}$ & $\begin{array}{c}4.78 \\
(1.01- \\
22.71)\end{array}$ \\
\hline$p$-value & \multicolumn{3}{|c|}{0,13} & \multicolumn{3}{|c|}{0.19} & \multicolumn{3}{|c|}{0.055} \\
\hline \multicolumn{10}{|l|}{ Tumor size } \\
\hline T1 & $\begin{array}{c}46 \\
(53.5)\end{array}$ & $\begin{array}{c}35 \\
(40.7)\end{array}$ & $5(5.8)$ & $\begin{array}{c}15 \\
(17.2)\end{array}$ & $52(59,8)$ & $20(23.0)$ & $\begin{array}{c}63 \\
(73.3)\end{array}$ & $\begin{array}{c}22 \\
(25.6)\end{array}$ & $1(1.2)$ \\
\hline T2-4 & $\begin{array}{c}89 \\
(47.8)\end{array}$ & $\begin{array}{c}78 \\
(42.4)\end{array}$ & $18(9.8)$ & $\begin{array}{c}65 \\
(34.6)\end{array}$ & $85(45.2)$ & $38(20.2)$ & $\begin{array}{c}130 \\
(70.1)\end{array}$ & $\begin{array}{c}45 \\
(24.5)\end{array}$ & $10(5.4)$ \\
\hline OR $(95 \% \mathrm{CI})$ & 1.00 & $\begin{array}{c}1.16 \\
(0.68- \\
1.99)\end{array}$ & $\begin{array}{c}1.57 \\
(0.58- \\
4.22)\end{array}$ & 1.00 & $\begin{array}{l}0.38 \\
(0.20- \\
0.73)\end{array}$ & $\begin{array}{c}0.44 \\
(0.20- \\
0.96)\end{array}$ & 1.00 & $\begin{array}{c}1.01 \\
(0.56- \\
1.83)\end{array}$ & $\begin{array}{l}4.96 \\
(0.62- \\
39.59)\end{array}$ \\
\hline$p$-value & \multicolumn{3}{|c|}{0,62} & \multicolumn{3}{|c|}{0.009} & \multicolumn{3}{|c|}{0,18} \\
\hline \multicolumn{10}{|l|}{ Stage } \\
\hline I & $\begin{array}{c}50 \\
(44.6)\end{array}$ & $\begin{array}{c}50 \\
(44.6)\end{array}$ & $\begin{array}{c}12 \\
(10.7)\end{array}$ & $\begin{array}{c}27 \\
(24.1)\end{array}$ & $57(50.9)$ & $28(25,0)$ & $\begin{array}{c}78 \\
(69.6)\end{array}$ & $\begin{array}{c}31 \\
(27.7)\end{array}$ & $3(2.7)$ \\
\hline st. I vsst. II & $\begin{array}{c}31 \\
(62,0)\end{array}$ & $\begin{array}{c}17 \\
(34,0)\end{array}$ & $2(4,0)$ & $\begin{array}{c}15 \\
(30,0)\end{array}$ & $22(44,0)$ & $13(26,0)$ & $\begin{array}{c}36 \\
(72,0)\end{array}$ & $\begin{array}{c}12 \\
(24,0)\end{array}$ & $2(4,0)$ \\
\hline OR $(95 \% \mathrm{CI})$ & 1.00 & $\begin{array}{c}0.55 \\
(0.27- \\
1.11)\end{array}$ & $\begin{array}{c}0.27 \\
(0.06- \\
1.28) \\
\end{array}$ & 1.00 & $\begin{array}{c}0.69 \\
(0.31- \\
1.55) \\
\end{array}$ & $\begin{array}{c}0.84 \\
(0.34- \\
2.08) \\
\end{array}$ & 1.00 & $\begin{array}{c}0.84 \\
(0.39- \\
1.82) \\
\end{array}$ & $\begin{array}{c}1.44 \\
(0.23- \\
9.03)\end{array}$ \\
\hline p-level & \multicolumn{3}{|c|}{0,08} & \multicolumn{3}{|c|}{0,67} & \multicolumn{3}{|c|}{0,82} \\
\hline st. I vsst. III & $\begin{array}{c}42 \\
(50,0)\end{array}$ & $\begin{array}{c}35 \\
(41.7)\end{array}$ & $7(8.3)$ & $\begin{array}{c}27 \\
(32.5)\end{array}$ & $47(56.6)$ & $9(10.8)$ & $\begin{array}{c}60 \\
(71.4)\end{array}$ & $21(25)$ & $3(3.6)$ \\
\hline
\end{tabular}




\begin{tabular}{|c|c|c|c|c|c|c|c|c|c|}
\hline OR $(95 \% \mathrm{CI})$ & 1.00 & $\begin{array}{c}0.82 \\
(0.45- \\
1.49)\end{array}$ & $\begin{array}{c}0.67 \\
(0.24- \\
1.85)\end{array}$ & 1.00 & $\begin{array}{c}0.81 \\
(0.42- \\
1.57)\end{array}$ & $\begin{array}{c}0.37 \\
(0.16- \\
0.84)\end{array}$ & 1.00 & $\begin{array}{c}0.89 \\
(0.46- \\
1.70)\end{array}$ & $\begin{array}{c}1.27 \\
(0.25- \\
6.50)\end{array}$ \\
\hline p-value & \multicolumn{3}{|c|}{0.66} & \multicolumn{3}{|c|}{0,012} & \multicolumn{3}{|c|}{0,89} \\
\hline st. I vsst. IV & $\begin{array}{c}3 \\
(17,6)\end{array}$ & $9(52,9)$ & $5(29,4)$ & $9(52,9)$ & $3(17,6)$ & $5(29,4)$ & $\begin{array}{c}13 \\
(76,5)\end{array}$ & $2(11,8)$ & $2(11,8)$ \\
\hline OR $(95 \% \mathrm{CI})$ & 1.00 & $\begin{array}{c}1.76 \\
(0.55- \\
5.64) \\
\end{array}$ & $\begin{array}{c}2.40 \\
(0.50- \\
11.48) \\
\end{array}$ & 1.00 & $\begin{array}{c}0,15(0,04- \\
0,62)\end{array}$ & $\begin{array}{c}0.53 \\
(0.16- \\
1.81) \\
\end{array}$ & 1.00 & $\begin{array}{c}0.39 \\
(0.08- \\
1.83) \\
\end{array}$ & $\begin{array}{c}3.90 \\
(0.59- \\
25.63)\end{array}$ \\
\hline p-value & \multicolumn{3}{|c|}{0,47} & \multicolumn{3}{|c|}{0,015} & \multicolumn{3}{|c|}{0,14} \\
\hline \multicolumn{10}{|c|}{ Regional lymph node metastases } \\
\hline N0 & $\begin{array}{c}69 \\
(48.2) \\
\end{array}$ & $\begin{array}{c}62 \\
(43.4)\end{array}$ & $12(8.4)$ & $\begin{array}{c}33 \\
(23.1)\end{array}$ & $71(49.6)$ & $39(27.3)$ & $\begin{array}{c}101 \\
(70.6)\end{array}$ & $\begin{array}{c}37 \\
(25.9)\end{array}$ & $5(3.5)$ \\
\hline $\mathrm{N} 0-1,2,3$ & $\begin{array}{c}68 \\
(51.1)\end{array}$ & $\begin{array}{c}52 \\
(39.1)\end{array}$ & $13(9.8)$ & $\begin{array}{c}47 \\
(35.6)\end{array}$ & $66(50,0)$ & $19(14.4)$ & $\begin{array}{c}95 \\
(71.4)\end{array}$ & $\begin{array}{c}32 \\
(24.1)\end{array}$ & $6(4.5)$ \\
\hline OR $(95 \% \mathrm{CI})$ & 1.00 & $\begin{array}{c}0.85 \\
(0.52- \\
1.40) \\
\end{array}$ & $\begin{array}{l}1.10 \\
(0.47- \\
2.58) \\
\end{array}$ & 1.00 & $\begin{array}{c}0.65 \\
(0.37- \\
1.14) \\
\end{array}$ & $\begin{array}{c}0.34(0.17- \\
0.69)\end{array}$ & 1.00 & $\begin{array}{c}0.92 \\
(0.53- \\
1.59) \\
\end{array}$ & $\begin{array}{c}1.28 \\
(0.38- \\
4.32) \\
\end{array}$ \\
\hline p-value & \multicolumn{3}{|c|}{0,75} & \multicolumn{3}{|c|}{0,0098} & \multicolumn{3}{|c|}{0,87} \\
\hline
\end{tabular}

Table 4:- Association between VEGF Haplotypes and Tumor Characteristics in the Belarusian Population.

\begin{tabular}{|c|c|c|c|c|c|c|c|c|}
\hline \multirow{3}{*}{ Haplotype } & \multicolumn{8}{|c|}{ Tumor size } \\
\hline & \multicolumn{2}{|c|}{ T1-T2 } & \multicolumn{2}{|c|}{ T1-T3 } & \multicolumn{2}{|l|}{ T1-T4 } & \multicolumn{2}{|c|}{$\mathrm{T} 1-\mathrm{T} 2-4$} \\
\hline & $\begin{array}{l}\text { OR }(95 \% \\
\text { CI) }\end{array}$ & $\mathrm{P}$ & $\begin{array}{c}\text { OR }(95 \% \\
\text { CI) }\end{array}$ & $\mathrm{P}$ & OR (95\% CI) & $\mathrm{P}$ & OR $(95 \%$ CI $)$ & $\mathrm{P}$ \\
\hline \multicolumn{9}{|l|}{$\begin{array}{l}-634 /- \\
2578 /+936\end{array}$} \\
\hline $\mathrm{G} / \mathrm{A} / \mathrm{C}$ & 1.00 & & 1.00 & --- & 1.00 & --- & 1.00 & --- \\
\hline $\mathrm{C} / \mathrm{C} / \mathrm{C}$ & $\begin{array}{l}2.31(1.29 \\
-4.12)\end{array}$ & 0.005 & $\begin{array}{c}1.49(0.63- \\
3.52)\end{array}$ & 0.37 & $\begin{array}{c}3.48(1.18- \\
10.24)\end{array}$ & 0.025 & $\begin{array}{c}2.13(1.24- \\
3.67)\end{array}$ & 0.0068 \\
\hline $\mathrm{G} / \mathrm{C} / \mathrm{C}$ & $\begin{array}{c}1.74(0.89 \\
-3.37)\end{array}$ & 0.1 & $\begin{array}{c}1.05(0.43- \\
2.56)\end{array}$ & 0.92 & $\begin{array}{c}3.18(1.04- \\
9.74)\end{array}$ & 0.046 & $\begin{array}{c}1.68(0.92- \\
3.07)\end{array}$ & 0.091 \\
\hline G/A/T & $\begin{array}{c}3.46(0.87 \\
-13.77)\end{array}$ & 0.08 & $\begin{array}{c}2.65(0.76- \\
9.26)\end{array}$ & 0.13 & $\begin{array}{c}2.96(0.70- \\
12.50)\end{array}$ & 0.14 & $\begin{array}{c}3.59(0.99- \\
13.09)\end{array}$ & 0.054 \\
\hline $\mathrm{C} / \mathrm{C} / \mathrm{T}$ & $\begin{array}{c}1.46(0.51 \\
-4.22)\end{array}$ & 0.48 & $\begin{array}{c}3.01(0.79- \\
11.50)\end{array}$ & 0.11 & $\begin{array}{c}3.86(0.88- \\
17.00)\end{array}$ & 0.077 & $\begin{array}{c}1.87(0.74- \\
4.69)\end{array}$ & 0.18 \\
\hline $\mathrm{G} / \mathrm{C} / \mathrm{T}$ & $\begin{array}{c}0.55(0.11 \\
-2.87)\end{array}$ & 0.48 & $\begin{array}{c}0.71(0.15- \\
3.23)\end{array}$ & 0.66 & $\begin{array}{c}6.47(0.59- \\
71.05)\end{array}$ & 0.13 & $\begin{array}{c}0.79(0.28- \\
2.27)\end{array}$ & 0.67 \\
\hline $\mathrm{C} / \mathrm{A} / \mathrm{C}$ & $\begin{array}{c}0.65(0.10 \\
-4.41)\end{array}$ & 0.66 & $\begin{array}{l}0.00(- \text { Inf - } \\
\text { Inf) }\end{array}$ & 1 & 0.00 (-Inf - Inf) & 1 & $\begin{array}{c}0.41(0.06- \\
2.75)\end{array}$ & 0.36 \\
\hline $\mathrm{C} / \mathrm{A} / \mathrm{T}$ & $\begin{array}{c}0.90(0.01 \\
-74.55)\end{array}$ & - & - & - & - & - & $\begin{array}{c}0.68(0.01- \\
75.61)\end{array}$ & 0.87 \\
\hline \multirow{3}{*}{ Haplotype } & \multicolumn{8}{|c|}{ Stage } \\
\hline & \multicolumn{2}{|c|}{ I-II } & \multicolumn{2}{|c|}{ I-III } & \multicolumn{2}{|l|}{ I-IV } & \multicolumn{2}{|c|}{ I-III-IV } \\
\hline & $\begin{array}{l}\text { OR }(95 \% \\
\text { CI) }\end{array}$ & $\mathrm{P}$ & $\begin{array}{c}\text { OR }(95 \% \\
\text { CI })\end{array}$ & $\mathrm{P}$ & OR $(95 \%$ CI $)$ & $\mathrm{P}$ & OR $(95 \% \mathrm{CI})$ & $\mathrm{P}$ \\
\hline $\begin{array}{l}-634 /- \\
2578 /+936\end{array}$ & & & & & & & & \\
\hline G/A/C & 1.00 & --- & 1.00 & & 1.00 & --- & 1.00 & --- \\
\hline $\mathrm{C} / \mathrm{C} / \mathrm{C}$ & $\begin{array}{c}1.06(0.54 \\
-2.08)\end{array}$ & 0.87 & $\begin{array}{c}1.50(0.82- \\
2.73)\end{array}$ & 0.19 & $\begin{array}{c}1.75(0.71- \\
4.27)\end{array}$ & 0.22 & $\begin{array}{c}1.36(0.82- \\
2.23)\end{array}$ & 0.23 \\
\hline $\mathrm{G} / \mathrm{C} / \mathrm{C}$ & $\begin{array}{c}2.61(1.24 \\
-5.46)\end{array}$ & 0.012 & $\begin{array}{c}2.70(1.30- \\
5.60)\end{array}$ & 0.0085 & $\begin{array}{c}0.97(0.26- \\
3.62)\end{array}$ & 0.97 & $\begin{array}{c}2.30(1.27- \\
4.16)\end{array}$ & 0.0061 \\
\hline G/A/T & $3.17(1.11$ & 0.033 & $1.92(0.59-$ & 0.28 & $2.11(0.57-$ & 0.26 & $2.23(0.85-$ & 0.1 \\
\hline
\end{tabular}




\begin{tabular}{|c|c|c|c|c|c|c|c|c|}
\hline & $-9.11)$ & & $6.25)$ & & 7.72) & & $5.85)$ & \\
\hline $\mathrm{C} / \mathrm{C} / \mathrm{T}$ & $\begin{array}{l}0.00 \text { (-Inf - } \\
\text { Inf) }\end{array}$ & 1 & $\begin{array}{c}1.84(0.68- \\
4.97)\end{array}$ & 0.23 & $\begin{array}{c}0.75(0.09- \\
6.13)\end{array}$ & 0.79 & $\begin{array}{c}1.50(0.62- \\
3.59)\end{array}$ & 0.37 \\
\hline $\mathrm{G} / \mathrm{C} / \mathrm{T}$ & $\begin{array}{c}0.74(0.16 \\
-3.45) \\
\end{array}$ & 0.71 & $\begin{array}{c}0.84(0.24- \\
2.94) \\
\end{array}$ & 0.79 & 0.00 (-Inf - Inf) & 1 & $\begin{array}{c}0.65(0.22- \\
1.95) \\
\end{array}$ & 0.45 \\
\hline $\mathrm{C} / \mathrm{A} / \mathrm{C}$ & $\begin{array}{l}0.00 \text { (-Inf - } \\
\text { Inf) }\end{array}$ & 1 & $\begin{array}{l}0.00 \text { (-Inf - } \\
\text { Inf) }\end{array}$ & 1 & $\begin{array}{c}1.58(0.14- \\
17.49)\end{array}$ & 0.71 & $\begin{array}{c}0.29(0.03- \\
2.72)\end{array}$ & 0.28 \\
\hline $\mathrm{C} / \mathrm{A} / \mathrm{T}$ & $\begin{array}{l}0.00 \text { (-Inf - } \\
\text { Inf) }\end{array}$ & 1 & - & - & $\begin{array}{c}6.95(0.12- \\
395.80)\end{array}$ & 0.35 & 0.00 (-Inf - Inf) & 1 \\
\hline \multirow{3}{*}{ Haplotype } & \multicolumn{8}{|c|}{ Regional lymph node metastases } \\
\hline & \multicolumn{2}{|c|}{ N0-N1 } & \multicolumn{2}{|c|}{ N0-N2 } & \multicolumn{2}{|l|}{ N0-N3 } & \multicolumn{2}{|l|}{ N0-N1-3 } \\
\hline & $\begin{array}{c}\text { OR }(95 \% \\
\text { CI) }\end{array}$ & $\bar{P}$ & $\begin{array}{c}\text { O R(95\% } \\
\text { CI) }\end{array}$ & $\bar{P}$ & OR $(95 \% \mathrm{CI})$ & $\bar{P}$ & OR $(95 \%$ CI $)$ & $P$ \\
\hline $\begin{array}{l}-634 /- \\
2578 /+936\end{array}$ & & & & & & & & \\
\hline $\mathrm{G} / \mathrm{A} / \mathrm{C}$ & 1.00 & --- & 1.00 & --- & 1.00 & --- & 1.00 & --- \\
\hline $\mathrm{C} / \mathrm{C} / \mathrm{C}$ & $\begin{array}{c}1.74(0.96 \\
-3.15)\end{array}$ & 0.072 & $\begin{array}{c}1.38(0.76- \\
2.51)\end{array}$ & 0.29 & $\begin{array}{c}1.94(0.25- \\
14.91)\end{array}$ & 0.52 & $\begin{array}{c}1.57(0.97- \\
2.54)\end{array}$ & 0.066 \\
\hline $\mathrm{G} / \mathrm{C} / \mathrm{C}$ & $\begin{array}{c}2.98(1.50 \\
-5.92)\end{array}$ & 0.0022 & $\begin{array}{c}2.08(1.03- \\
4.20)\end{array}$ & 0.043 & $\begin{array}{c}3.20(0.36- \\
28.82)\end{array}$ & 0.3 & $\begin{array}{c}2.55(1.44- \\
4.50)\end{array}$ & 0.0014 \\
\hline G/A/T & $\begin{array}{c}2.13(0.85 \\
-5.32) \\
\end{array}$ & 0.11 & $\begin{array}{c}1.26(0.46- \\
3.43)\end{array}$ & 0.66 & --- & & $\begin{array}{c}1.65(0.76- \\
3.58) \\
\end{array}$ & 0.21 \\
\hline $\mathrm{C} / \mathrm{C} / \mathrm{T}$ & $\begin{array}{c}1.37(0.45 \\
-4.18)\end{array}$ & 0.58 & $\begin{array}{c}2.04(0.78- \\
5.32)\end{array}$ & 0.15 & --- & & $\begin{array}{c}1.70(0.73- \\
3.96)\end{array}$ & 0.22 \\
\hline $\mathrm{G} / \mathrm{C} / \mathrm{T}$ & $\begin{array}{c}1.14(0.28 \\
-4.55)\end{array}$ & 0.86 & $\begin{array}{c}1.11(0.29- \\
4.20)\end{array}$ & 0.88 & --- & & $\begin{array}{c}1.12(0.37- \\
3.39)\end{array}$ & 0.85 \\
\hline $\mathrm{C} / \mathrm{A} / \mathrm{C}$ & $\begin{array}{l}0.00 \text { (-Inf - } \\
\text { Inf) }\end{array}$ & 1 & $\begin{array}{c}0.82(0.08- \\
8.04)\end{array}$ & 0.87 & --- & & $\begin{array}{c}0.45(0.05- \\
4.33)\end{array}$ & 0.49 \\
\hline $\mathrm{C} / \mathrm{A} / \mathrm{T}$ & $\begin{array}{l}0.00 \text { (-Inf - } \\
\text { Inf) }\end{array}$ & 1 & $\begin{array}{l}0.00 \text { (-Inf - } \\
\text { Inf) }\end{array}$ & 1 & --- & & $0.00(-\operatorname{Inf}-\operatorname{Inf})$ & 1 \\
\hline
\end{tabular}

Conclusion:-

Polymorphic variants of rs699947, rs3025039 VEGF gene influenced the histological type of tumor, tumor size and metastasis, whereas haplotype $-634 \mathrm{C} /-2578 \mathrm{C} /+936 \mathrm{C} /$ and $-634 \mathrm{G} /-2578 \mathrm{C} /+936 \mathrm{C} /$ increase aggressiveness of the NSCLC.

\section{Conflict of interest:-}

The authors declare no conflict of interest.

\section{References:-}

1. Awata, T. (2002): A common polymorphism in the 50-untranslated region of the VEGF gene is associated with diabetic retinopathy in type 2 diabetes. Diabetes, 51: 1635-1639.

2. Cianfrocca R, Tocci P, Rosanò L, Caprara V, Sestito R, et al. (2016): Nuclear $\beta$-arrestin1 is a critical cofactor of hypoxia-inducible factor- $1 \alpha$ signaling in endothelin-1-induced ovarian tumor progression. Oncotarget., 7(14): 17790-17804.

3. Dhakal, H.P. Naume, B M. Synnestvedt, E. Borgen, R. Kaaresen, E. et al. (2012): Expression of vascular endothelial growth factor and vascular endothelial growth factor receptors 1 and 2 in invasive breast carcinoma: prognostic significance and relationship with markers for aggressiveness. Histopathology, 61: 350-364.

4. Fukuda, H. Tsuchiya N., Narita S., Kumazawa T., Horikawa Y., et al. (2007): Clinical implication of vascular endothelial growth factor T-460C polymorphism in the risk and progression of prostate cancer. Oncol Rep., 18:1155-1163.

5. Furrukh M, Al-Moundhri M, Zahid KF, Kumar S, Burney I.. (2013): Individualised Treatment of Metastatic Non-Small-Cell Lung Carcinoma (NSCLC)., 13(2): 202-217. 
6. Heist RS, Zhai R, Liu G, Zhou W, Lin X, et al. (2008): VEGF Polymorphisms and Survival in Early-Stage Non-Small-Cell Lung Cancer. Journal of Clinical Oncology, 29(6): 856-862.

7. Jain, L. Vargo C.A, Danesi R, Sissung T.M., Price D.K., et al. (2009): The role of vascular endothelial growth factor SNPs as predictive and prognostic markers for major solid tumors., 8:2496-508.

8. Jemal A, Clegg LX, Ward E, Ries LA, Wu X, et al. (2004): Annual report to the nation on the status of cancer with a special feature regarding survival. Cancer., 101: 3-27

9. Kawakami, M., Furuhata T, Kimura Y, Yamaguchi K, Hata F, et al. (2003): Expression analysis of vascular endothelial growth factors and their relationships to lymph node metastasis in human colorectal cancer. $\mathrm{J}$ ExpClin Cancer Res., 22: 2229-2237.

10. Krippl P, Langsenlehner U, Renner W, Yazdani-Biuki B, Wolf G, et al. (2003): A common 936 C/T gene polymorphism of vascular endothelial growth factor is associated with decreased breast cancer risk. IntJ.Cancer., 106: 468 - 471.

11. Lambrechts D, Storkebaum E, Morimoto M, Del-Favero J, Desmet F, et al. (2003): VEGF is a modifier of amyotrophic lateral sclerosis in mice and humans and protects motoneurons against ischemic death. Nat. Genet., 34: 383-394.

12. Nasr HB, Chahed K, Bouaouina N, Chouchane L. (2008): Functional vascular endothelial growth factor -2578 C/A polymorphism in relation to nasopharyngeal carcinoma risk and tumor progression. ClinChimActa., 395(12):124-129.

13. Nakamura M, Abe Y, Tokunaga T. (2002): Pathological significance of vascular endothelial growth factor A isoform expression in human cancer., 52: 331-339.

14. Nowell, S.A. (2004): Gene-nutrient interactions in cancer etiology. Nutr Rev., 62(11): 427-438.

15. Park H., Park H, Lee DS, Yim MJ, Choi YH, et al. (2015): 3,3'-Diindolylmethane inhibits VEGF expression through the HIF- $1 \alpha$ and NF- $\kappa B$ pathways in human retinal pigment epithelial cells under chemical hypoxic conditions. Int J Mol Med., 36(1): 301-308.

16. Parkin DM, Bray F, Ferlay J. (2001): Estimating the world cancer burden: Globocan. Int J Cancer., 94(2):153156.

17. PengLv, Gang Chen, and Peng Zhang. (2014): Log odds of positive lymph nodes are superior to other measures for evaluating the prognosis of non-small cell lung cancer. Thorac Cancer., 5(6): 570-575.

18. Perrot-Applanat, M. M. Di Benedetto. (2012): Autocrine functions of VEGF in breast tumor cells: Adhesion, survival, migration and invasion. Cell Adh. Migr., 6:547-553.

19. Schneider B., Radovich M, Sledge GW, Robarge JD, Li L, et al. (2008): Association of polymorphisms of angiogenesis genes with breast cancer. Breast Cancer Res. Treat., 111: 157-163.

20. Shahbazi M, M. Shahbazi, A. Fryer, V. Pravica et al. (2002): Vascular endothelial growth factor gene polymorphisms are associated with acute renal allograft rejection. J Am Soc. Nephrol., 13: 260 - 4.

21. Sheng, Z. Guo-Ping W., Cong L., Muxiang Z. (2006): Eukaryotic initiation factor 4E (eIF4E) and angiogenesis: prognostic markers for breast cancer. BMC Cancer, 6: 231-243.

22. Slattery ML, Lundgreen A, Wolff RK (2014): VEGFA, FLT1, KDR and colorectal cancer: assessment of disease risk, tumor molecular phenotype, and survival. MolCarcinog., 50: E140-E150.

23. Watson C., Webb N., Bottomley M., Brenchley P. (2000): Identification of polymorphisms within the vascular endothelial growth factor (VEGF) gene: correlation with variation in VEGF protein production. Cytokine, 12: $1232-1235$.

24. http://seer.cancer.gov/csr 1975_2013 - date of access: 21.06.2016.

25. http://www.uicc.org/sites/main/files/private/TNM_Classification_of_Malignant_Tumours_ - date of access: 21.06.2016.

26. http://bioinfo.iconcologia.net/snpstats/start.htm - date of access: 21.06.2016 